\title{
Bulimia Nervosa and Dissatisfaction of Adolescent's Body Shape
}

\author{
Alice Maria de Souza-Kaneshima and Edilson Nobuyoshi Kaneshima \\ State University of Maringá. Maringá PR, \\ Brazil
}

\section{Introduction}

Bulimia nervosa is an eating disorder that affects young people and causes serious damage to life quality and death in extreme cases (Affenito \& Kerstetter, 1999; Cordás, 2004; Costa et al., 2008; Gucciardi et al., 2004). Since most people with the disorder have normal weight, the diagnosis of bulimia nervosa becomes a highly complex issue (Kaufman, 2000).

The etiology of bulimia nervosa has yet to be understood. However, low self-esteem, depression, social pressure on keeping oneself slim and a dissatisfaction with the body shape are factors that may be associated with the bulimia nervosa event, especially in the case of adolescents and female young adults (Affenito \& Kerstetter, 1999; Alvarez-Rayon et al., 2009; Costa et al., 2008; Crosby et al., 2009; Gucciardi et al., 2004; Jauregui-Lobera et al., 2008; Thompson \& Chad, 2000).

Excessive concern with weight gaining is not the only criterion for a diagnosis of bulimia nervosa. Nevertheless, adolescents with such concern have a seven-fold chance in developing some type of eating disorder (Grillo \& Silva, 2004).

The fact that many young people are not satisfied with their own body shape may be an effect of pre-conceived ideas on idealized body images taken from aesthetic values transmitted by society or by the social media (Andrade \& Bosi, 2003; Reato et al., 2000; Reato, 2002). The female adolescent finds herself in conflict between a fantasy-created image and her real body shape. From her perspective, there is a great difference between what is observed and what is desired. This event may lead towards dissatisfaction and low selfesteem which induces the development of eating disorders such as bulimia nervosa (Andrade \& Bosi, 2003; Mond et al., 2004; Reato, 2002; Silva et al., 2003).

Many authors agree that the most prevalent aspect of female dissatisfaction occurs in issues referring to weight and appearance. Many women, including those with normal weight or even slim ones, have the impression that they are overweight or even obese. This is the reason why their body image distortion mainly affects female adolescent and young adult females (Alvarez-Rayon et al., 2009; Cordas, 2004; Costa et al., 2008; Mond et al., 2004; Nunes et al., 2001).

Studies related to adolescent's psychological and eating behaviour alterations are important for the determination of factors involved in the development of eating disorders in young populations. The use of self-evaluation scales is an asset in the detection of possible eating disorders or of sub-clinic individuals (Kjelsas et al., 2004; Wichstrom, 1995). 
Bulimia nervosa affects males and females, although the latter are more prone to the disease. This is due to the fact that women have more conflicts related to meals, weight and body shape. Conflicts indeed change the female adolescents' emotional state; in their turn, they present a distorted body image and low self-esteem (Affenito \& Kerstetter, 1999; Gucciardi et al., 2004; Mond et al., 2004). Although many bulimic syndrome cases have been reported in young women under 18 years, the occurrence of such eating disorder is also on the increase in males (Affenito \& Kerstetter, 1999; Alvarez-Rayon et al., 2009; Appolinário \& Claudino, 2000; Costa et al., 2008; Gucciardi et al., 2004; Jauregui-Lobera et al., 2008; Kaufman, 2000).

Several authors report that patients with bulimic events are also highly concerned with weight gain. The patient is prone to use non-appropriate compensatory methods even twice a week. Self-evaluation of body image in these patients is greatly affected by societyidealized images of body shape and weight (Alvarez-Rayon et al., 2009; Cordás, 2004; Costa et al., 2008; Gucciardi et al., 2004; Jauregui-Lobera et al., 2008; Miranda, 2000; Pedrinola, 2002; Thompson \& Chad, 2000).

\section{The evolution of beauty standards}

The idea of a healthy and beautiful body underwent several changes throughout the ages. By the end of the Middle Ages the ideal feminine body emphasized its reproductive role with an underscoring of motherhood, as Botticelli's artistic representation of the Birth of Venus (1485) warrants. The beautiful and the desired female always featured a lady with a round body due to fat deposits in the waist, thighs, belly and breasts, round and full breasts (Castilho, 2001). Famines and lack of food were not infrequent during the period and a round-bodied female symbolized the strong woman with sufficient energy to face the vicissitudes of the time and protect her family (Almeida et al., 2005; Andrade \& Bosi, 2003).

At the start of the $16^{\text {th }}$ century any artifice to seek or enhance beauty was liable to punishment. Beauty was God's gift and the face should reveal the soul's innocence. Hands should be long, white and dainty, and tight corsets were mandatory so that the female bosom could be graceful and her body elegant. In the $17^{\text {th }}$ century etiquette and body posing were highly appreciated. Moreover, beauty was the female's asset although male aesthetics distanced itself from the signs of power in which it was enmeshed. More radical changes of concepts occurred in the $18^{\text {th }}$ century. Mirrors became popular and with them the possibility of observing the entire body, or rather, the body's profile, balance and movements, with a consequent increase in sensitiveness and awareness of one's own body. Walking was recommended by physicians so that one's posture could be strengthened and legs and arms mobilized (Vigarello, 2006).

In the 19th century other parts of the body began to be focused and notions of beauty limelighted shape and profile. Sales and use of cosmetics and make-ups increased throughout the century and the physical model of the female profile now comprised a tight waist and a puffed up bosom. The discovery of oxygen may have shown that large breasts symbolized life. By the end of the century while special emphasis was bequeathed to the legs, the beach was the site of leisure and rest (Vigarello, 2006).

The idealized female image of the beginning of the $20^{\text {th }}$ century was represented by two opposite standards: the first one comprised an erotic profile which could be found in the finde-siècle cafés full of females exhibiting rounded contours and pronounced tights; the second revealed a slim and thin profile. The latter definitely supplanted the former and 
advertisements featuring slim females became abundant. In fact, several massage methods were introduced to delete excesses in rounded profiles. It was during this period that a relationship between age, weight and height was established even though hard and fast rules were inexistent (Vigarello, 2006).

The end of the First World War brought about the female's plain and free shapes which displaced the erstwhile curve ideals. Women's wear of the 1920s abandoned the curvy outlines and corsets. Bodices were set aside. Since women started to support their breasts with vests that flattened their profile, during this period beauty was almost characterized by the absence of secondary female sexual traits. The female profile had an extended shape, legs were up for view and hairdressings were high (Castilho, 2001).

Fashion magazines of the 1920s demonstrated an association between professional life style and beauty care. Swimming became more frequent and dynamic moving half-naked bodies were exposed for anyone to look at and appreciate. Such a condition had an important influence on the concept of beauty since beauty became synonymous to a slim and muscular body with elegant and graceful movements. As a consequence, women started to maintain strict diets and extenuating physical exercises to decrease their body mass (Castilho, 2001; Vigarello, 2006).

In the wake of such a deep concern for weight loss the 1926 New York Times advertised that the New York Science Academy was calling a two-day conference to study "the explosion of food disturbances". Table 1 shows a 10-year historical series in which the ideal weight of women, height $1.60 \mathrm{~m}$, was suggested. The table below reveals the loss of weight trend according to the magazine Votre Beauté.

\begin{tabular}{|l|l|}
\hline PERIOD & BODY MASS \\
\hline January 1929 & $60.0 \mathrm{~kg}$ \\
\hline April 1932 & $54.0 \mathrm{~kg}$ \\
\hline August 1932 & $52.0-53.0 \mathrm{~kg}$ \\
\hline May 1939 & $51.5 \mathrm{~kg}$ \\
\hline
\end{tabular}

Table 1. Description of the ideal weight for women, height $1.60 \mathrm{~m}$, at the beginning of the $20^{\text {th }}$ century

Table 2 shows some measurements that the female figure, height $1.60 \mathrm{~m}$, was expected to have in the 1930s, as described in the magazines Votre Beauté and Marie Claire. A trend had been introduced so that rates became smaller and smaller, corroborating the suggestion of progressive slimness (Vigarello, 2006). Progressive slimness of the female body throughout the ages may also be deduced from requirements on the agenda of Miss America Contest. In 1921 the Body Mass Index (BMI) of most of the candidates was 21.2 whereas in 1940 it decreased to 19.5. Specialized magazines exhibited the perfect body profile of film stars, and female editors were vying in giving counsels to the readers that all women may possess a

\begin{tabular}{|l|c|c|c|}
\hline & $\begin{array}{c}1933 \text { (Votre } \\
\text { Beautê) }\end{array}$ & $\begin{array}{c}1938 \text { (Marie } \\
\text { Claire) }\end{array}$ & $\begin{array}{c}1939 \text { (Votre } \\
\text { Beauté) }\end{array}$ \\
\hline Bosom & $83 \mathrm{~cm}$ & $85 \mathrm{~cm}$ & $81 \mathrm{~cm}$ \\
\hline Hips & $87 \mathrm{~cm}$ & $85 \mathrm{~cm}$ & $75 \mathrm{~cm}$ \\
\hline Waist & $65 \mathrm{~cm}$ & $60 \mathrm{~cm}$ & $58 \mathrm{~cm}$ \\
\hline
\end{tabular}

Table 2. Measurements of the female figure, height $1.60 \mathrm{~m}$ 
beautiful body if discipline, physical culture and adequate diets were practiced. Their motto was that "there are no ugly women but women who do not take care of their body" (Vigarello, 2006). Make-up had a basic role during the first half of the $20^{\text {th }}$ century. In fact, the female face was considered uncared for in its absence. Concern with cellulite and creases was followed by repairing and aesthetic surgeries (Vigarello, 2006).

Body cult from the 1950s onward became a rage and won an unprecedented social dimension. Democratization of the beauty stance was rife. The social media exerted a great influence on people, spread the craze for fashion, expanded the consumption of beauty products, broadcasted the changes that occurred in the bodies of famous people who underwent plastic surgery and idealized physical appearance as a basic factor in female and male identity (Castilho, 2001).

In 1960 publicity on beauty products and the like made up 60 to $70 \%$ of women's fashion magazines, or rather, the double of the number in the 1930s. Further, as from the 1960s, the male body underwent a slimming process and men started to be concerned more and more with their aesthetics. Simultaneously the start of the feminization of body building could be observed. Consequently, beauty was not a criterion restricted to define the female or the male gender since both sought to model their bodies on slimness and by athletic and defined shapes (Almeida et al., 2005; Andrade \& Bosi, 2003; Ferriani et al., 2005; Oliveira \& Bosi, 2003). Linear shapes became a warrant of efficiency, agility, elegance and flexibility.

Cosmetics, make-up, aesthetic surgery and physical exercises triggered men and women to have an attractive body profile. Excuses for such complaints as being "not according to the figure" were severely rejected. An ugly person is a person who wants to be ugly and only those who want to age will get old. The body figure is shown to be a personal success since "fat and unsightly subjects do not exist; only lazy ones do" (Castilho, 2001).

The above shows that people may adopt any strategy to have the body they desire, including extremely restrictive diets and abuse in anorexigenous drugs, laxatives and diuretics. The use of anabolic hormones, excessive physical activities and numberless surgeries for the correction of small body defects may be the subjects' strategies to have an adequate muscular mass.

A study undertaken in the state of São Paulo, Brazil, with men and women featuring normal weight showed that $50 \%$ were unsatisfied with their bodies and $67 \%$ of the females would undergo plastic surgery to have the body they desire. This information corroborates the fact that Brazil is second (after the USA) in the number of cosmetic plastic surgeries (Finger, 2003). Such dissatisfaction reveals that the feminine body's ideal is gradually distancing itself from current female profiles (Hesse-Biber et al., 1987).

The fact that the number of obese people has tremendously increased in Western countries, including Brazil, exemplifies the situation previously described. The main causes are mainly an increase in the intake of hypercaloric food with high saturated fat rates and a sedentary life style that triggered an increase in leisure and a decrease in physical activities (Schwartz \& Brownell, 2004; Stettler, 2004). Whereas in general people have increased their body mass, the social media insists in broadcasting the progressively slim person. Thus, current beauty standards require slimmer anthropometric measurements (Morrison et al., 2004; Schwartz \& Brownell, 2004).

Although the physical consequences of obesity have been adequately described, the psychological and social consequences require further investigation even though they have already been established in the literature (Fonseca \& Matos, 2005). Body cult is directly associated with power, beauty and social mobility and thus an increase in body mass may 
amplify dissatisfaction with one's body, especially among children and young people (Striegel-Moore et al., 2000, Striegel-Moore, 2001).

\section{Aetiology and the establishment of body dissatisfaction}

Since the two-year-old child is already self-aware of its identity and recognizes its body image reflected in the mirror, the body image may be developed concomitantly to the development of the human body (Castilho, 2001). As a rule, body images are dynamic, changeable and directly related to the outside world (Tavares, 2003). The distortion of body perception may occur when the subjects overestimate or underestimate their body size and form. Social and cultural influences, pressures by the social media and the continuous search for an ideal body standard associated with achievements and happiness are the main causes of changes in body image and cause deep dissatisfaction in individuals, especially in women (Conti et al., 2005a,b).

Young people undergo constant psychological, emotional, somatic and cognitive changes which contribute towards deep concern with physical appearance and a craze for the ideal body (Tavares, 2003). The body dissatisfaction developed by adolescents may be related to changes in their self-image and self-esteem, coupled to excessive preoccupations with weight, body form and fat. The above alterations and concerns show that there is a discrepancy between the perception and the desire for a specific body size and shape which may predispose young people to develop psychological disorders (Almeida et al., 2005; Conti et al., 2010; Neumark-Sztainer et al., 2006; Smolak et al., 1999). Food intake, self-esteem and physical and cognitive performance depend on the intensity of this dissatisfaction and may be the cause of altering several aspects in the subjects' life (Smolak \& Levine, 2001).

It should be underscored, however, that disturbances in body perception are not merely a trait proper to young people who develop some type of eating disorder (Branco et al., 2006). In fact, body dissatisfaction, excessive concern with weight and a history of restrictive diets during adolescence are predisposing factors for the development of eating disorder behaviour such as bulimia nervosa, anorexia nervosa and binge eating disorder (Stein, et al., 1998). The social media, parents and friends are accountable for social comparisons on the physical aspects and idealizing concepts of slimness. They are thus related with the development of body dissatisfaction and, consequently, with low self-esteem, limitations in psychological and social performance and depression conditions (Robinson et al., 2001; Sands \& Wardle, 2003; Stice, et al., 2000).

The social media is accountable for food behaviour disorders or the body image. In fact, it not merely broadcasts images of perfect body forms but stimulates the intake of non-healthy food. Since magazines, films and advertisements publish images of young people with slim, muscular bodies, they induce individuals to establish an idea of beauty which is totally personal, characterized by unreachable aesthetic standards, in spite of all the diversity and singularity presented (Saikali et al., 2004).

Whereas by the end of the $20^{\text {th }}$ century, human manikins weighed $8 \%$ less than the average women at that time, currently they weigh $23 \%$ less. The difference may be associated with a decrease in the models' weight but also with women's weight gain in general. Body dissatisfaction, taken to be a standardized item in Western women, may be attributed to an increasing social and cultural pressure imposed by the social media in its portrayal of the ideal physical profile such as an unreal slimness for females and a muscular body for males (Becker et al., 2002; Rodin, et al., 1985; Stice et al., 2002). Such body image corresponds to 
that to which young people are constantly exposed to in advertisements, musical videos and films (Morrison et al., 2004; Stice \& Shaw, 2002; Stice \& Whitenton, 2002).

Feminine body dissatisfaction may be related to the social concepts advertised by the media which valorises and defines the slim body as physically more attractive and compensating; as a contrast, fat people's profiles are considered non-attractive and non-appealing. This situation reveals the female trend to acquire a body which will be an object of desire (Stormer \& Thompson, 1996). Most TV film stars are slim and only 5\% may be classified as fat (Silverstein et al., 1986).

Since human manikins advertised in women's magazines are represented statically, they reinforce the idea that the body is just an ornament (Duquin, 1989). Fashion magazines are important sources of information on beauty and excellence in form. Young women, who are their most frequent readers, demonstrate high dissatisfaction levels with regard to body form and most probably are prone to alter their social behaviour and food habits, such as practicing exhausting physical exercises or shunning meals, to decrease their body weight (Ferriani et al., 2005; Vilela et al., 2004). Women's constant contact with ideal body images advertised by the social media increases the occurrence of attitudes and behaviours which characterize eating disorders such as bulimia nervosa (Stice et al., 1994).

The social media also advertises the ideal male body as essentially muscular. It is actually a situation very similar to that among women where the male body is also an object of desire (Sommers-Flanagan et al., 1993). Several studies showed that most interviewed people had a hard conviction that the male body should be muscular while few replied that slimness is the true characteristic of the ideal male body (Murray et al., 1996). Consequently, very slim or very fat males represent a negative body image and, as a rule, are not in the media's limelight (Silverstein et al., 1986; Morrison et al., 2004). Concerns on the proper physical male profile have been intensified since the 1960s, with special emphasis on strength and body building so that the muscular body could be constructed (Petrie et al., 1996).

Since children aged between 8 and 11 years were aware of the slim body as the ideal to be attained, it may be surmised that their perception has been under the influence of the social media which is accountable for the broadcasting of body images of film stars and models as highly attractive and imitable (Cusumano \& Thompson, 2001). A study on young females, aged between 12 and 29, from the southern region of Brazil, was undertaken. Most of the women desired to have size and body mass less than their present condition even though only one third of this group was classified with a BMI equivalent to overweight or obesity (Nunes et al., 2003).

Parents and friends, along with the social media, construct body dissatisfaction in people (Sands \& Wardle, 2003). Eating habits and a body image may be built during the preadolescence period, although it is not an exclusive adolescence problem (Robinson, 2001). Concern with body weight afflicts 6- and 7-year-old girls due to concepts transmitted by society on what is attractive and graceful. These ideas foregrounding the girls' awareness on physical attractiveness, may very well be a reproduction of their mothers' opinions and attitudes (Castilho, 2001, Davison et al., 2000; Lowes \& Tiggemann, 2003)

In fact, the desire to be slim is manifest at the very onset of puberty. There is, however, much evidence that even pre-puberty children are worried about their body's shape and loss of weight is a great concern (Carvalho et al., 2005). Dissatisfaction and concern with the body and their repercussions were reported in a population-based investigation in the southern region of Brazil, comprising students within the $8-11$ years bracket. In fact, $82 \%$ of the children desired a different body form since they manifested low self-esteem and 
revealed perception levels with regard to their parents' and friends' expectations on their featuring a slim body (Pinheiro, 2003). Dissatisfaction with body shape already affects a great number of pre-adolescents, even in those with adequate weight. Regardless of nutrition state and sex, excessive concern with weight shows that many pre-adolescents are under pressure to adopt beauty stereotypes (Triches \& Giugliani, 2007). Research reveals that during the first years of adolescence parents exert a great influence on their children's physical appearance and lifestyle (Robinson, 2001; Smolak at al., 1999).

Obese children are unhappy and dissatisfied with weight excess and reveal psychic sufferings, low self-esteem and insecurity due to jokes and pranks practiced on them by their school mates (Braet, et al., 1997). Parents of 5-year-old overweight girls reported very high levels of concern with regard to the body mass of their daughters when compared with those whose daughters' weight was "normal". Very early in life these girls are concerned with their body: whereas they normally reveal low body esteem, their knowledge on nutrition and diets is considerable (Abramovitz \& Birch, 2000; Davison \& Birch, 2001).

Further studies are required to have an in-depth evaluation on the origin and consequences of children's dissatisfaction with regard to their body, taking into account the degree of dissatisfaction and family, social and cultural influences. However, the above information is enough to make parents, educators and health professionals on the look out for such a high prevalence in body dissatisfaction among pre-adolescent children so that the necessary strategies for a better body satisfaction could be taken. The literature has abundant studies on the theme of the body in adolescence and on its influence in the subjects' health. In fact, several investigations report that 25 to $80 \%$ are not satisfied with their body (Stice \& Whitenton, 2002). Western society highly values the slim and graceful body and fashion clothes are manufactured small size to this end. This condition causes a lack of body satisfaction in overweight subjects or in people with excessive weight, which is also associated with health concerns. In fact, the increasing number of obese people within a population, especially among children and adolescents, is a case of public health since they are in danger of developing diseases such as hypertension and Type 2 diabetes, coupled to problems in the spine, in bone articulations and in the lower members (Carvalho et al., 2005).

Overweight children and adolescents reveal a high rate of body dissatisfaction and a negative impact on the development of their self-image (Carvalho et al., 2005; Conti, 2005a,b; Davison \& Birch 2001; Erling \& Hwang, 2004). However, lack of satisfaction is not exclusive to this group since it has also been reported in over 15-year-old adolescents. Except those who are very slim, practically all desire to lose weight (Wardle \& Cooke, 2005). Children and adolescents within the 9-16 years bracket have low self-esteem due to their physical characteristics, and their happiness and intelligence levels are lower when compared with slim or eutrophic types (Paxton et al., 1991). The above situation demonstrates that self-perception with regard to the body type may cause serious interference on the body.

Most girls develop an awareness of their body form in the wake of their observations of their parents' habits and attitudes. The family is actually the primary socializing agent and may influence the perceptive self-evaluation of the children and the development of their habits (Hill \& Franklin, 1998). Parents may have an influence on their offspring's body dissatisfaction when they show concern with regard to their children's weight. This concern may occur implicitly when access to certain food is monitored or restricted, or explicitly when the weight and body form of other children are criticized or compared (Birch \& Fisher, 1998). 
Several non-overweight adolescents have reported their feeling on finding themselves fat. The feeling is associated with the body perception acquired during childhood and is related to parents' expectations with regard to children's ideal weight. Actually parents have a direct influence on their children's look up till the first year of adolescence. Moreover, the mother's excessive worry on the daughters' weight may decrease the body form perception regardless of their weight (Davison \& Birch, 2001; Pinheiro \& Giugliani , 2006a).

Since the role of the female model is proper to mothers and it is a well-known fact that they influence their children's food habits since childhood, it may be remarked that the highest rates of body dissatisfaction in children and young people may be related to the mothers' opinion with regard to their children's weight (Hill \& Franklin, 1998; Keel et al., 1997; Mukai, 1996). Body satisfaction level in adolescents and the adoption and the frequency of diets reflect the mothers' attitudes and concepts. This fact reveals that adolescents' body dissatisfaction is not exclusively affected by their body self-awareness but also by the behaviour of their mothers (Hill \& Franklin, 1998).

The mother's schooling level has been employed to assess economic social level. Daughters whose mothers have had less than eight years of schooling revealed an increased predisposition with regard to body dissatisfaction level. Such predisposition may be related to the need of acceptance by the social milieu since complying with the fashionable beauty standard may increase their possibility of social elevation due to their insertion within the artistic or fashion status (Cusumano \& Thompson, 2001). However, several authors remark that female adolescents of the higher social classes also have greater concerns with the body shape and size (Ogden \& Thomas, 1999). The above divergent results may be due to the employment of different research tools and different population samples. No significant difference in the proportion of subjects with or without body dissatisfaction was perceived in a study undertaken with several people with different ethnic and social-economical class backgrounds (Wang et al., 2005). Although parents may have an impact on boys so that they may gain weight and develop their muscles, further studies are required to evaluate the parents' influence in the boys' body image (Ricciardelli \& McCabe, 2001).

Friends have a great impact on socialization during the period of adolescence and social comparison is a highly employed mechanism among them (Lattimore \& Butterworth, 1999). Concerns in body weight among adolescents in the upper high school and a great probability of taking up restrictive diets may reflect the impact exerted by female friends. Several authors discuss that female friends' influence in late adolescence is higher than that provided by mothers with regard to diet attitudes and behaviour (Mukai, 1996; Taylor et al., 1998). Lack of body satisfaction among male adolescents is also related to the influence of friends and of the social media. Parents' impact is low during this period (O'Koon, 1997; Ricciardelli, et al., 2000).

As a rule, social comparison is proper to adolescents due to exhibited similar traits. Such a comparison may be related to the bearing for more or for less, and also to the characteristics of the target. When subjects with characteristics below their interest levels are compared, there is an automatic increase in subjective well-being; however, if social comparisons are directed towards subjects with better physical traits, the former subjects' well-being levels and their self-evaluation in attractiveness decrease considerably (Wheeler \& Miyake, 1992). When target characteristics are taken into account, the general target consists of information provided by the media which is a powerful means to influence idealized standards presented by the specific target provided by friends and family (Irving, 1990). 
Attractiveness self-evaluation decreases in subjects constantly exposed to the professional models in advertisements or fashion (Martin \& Kennedy, 1993; Thornton \& Moore, 1993). However, females who have taken up famous people (a general target) as a reference for their physical beauty standard also exhibited a decrease in their self-evaluation of attractiveness. As a consequence, they are prone to take up abnormal weight control practices such as vomit induction (Heinberg \& Thompson, 1992).

A Canadian study on adolescents within the 15-19 age bracket showed that male and female groups had an inverse relationship with regard to their evaluation of body image, selfesteem and body satisfaction. Several male adolescents considered themselves very slim, or rather, with less musculature than male actors and models, with the consequent need to increase their muscle mass. On the other hand, female adolescents had a body perception of obese people. Such changes in body perception may be related to their exposition to the media through which ambiguous concepts on body form are acquired. They thus underwent an intense general social comparison which, as a rule, brings about low levels of self-esteem (Morrison et al., 2004).

\section{Methodological aspects in the study of dissatisfaction with body image}

People who are extremely worried with their physical appearance are also susceptible to a negative or distorted body image (Castilho, 2001). Recent studies show that dissatisfaction with the body has reached alarming levels and has affected people in several age brackets (Conti, 2008; Coqueiro et al., 2008; Tribess et al., 2010; Triches \& Giugliani, 2007).

Leonhard and Barry (1998) remark that the very first studies on body image were restricted to and underscored body measurements, or rather, they focused on subjects classified as obese according to the BMI. The ideal current standard of feminine beauty corresponds to extreme slimness, whereas obesity is a negative factor in people's life. A high BMI is also related to discontent with one's body (Robinson et al., 2001).

Several analyses have shown that overweight school children and adolescents manifest low self-esteem and dissatisfaction with their body image when they compare themselves to eutrophic schoolmates (Gleaves et al., 1995; Pinheiro \& Giugliani, 2006a; Stice et al., 1996; Tiggemann, 1994). An investigation among students in the USA showed that body dissatisfaction featuring weight concern is highly prevalent among both sexes, in different ethnic groups and in social and economical classes. In fact, high BMI rates were always related to body dissatisfaction (Robinson et al., 2001).

It has been verified in current study that most eutrophic girls desire to be slimmer in contrast to boys' ideal for a bigger body or a bigger body form (Robinson et al., 2001) From the feminine point of view the ideal beauty stereotype is basically a lean and slim body, similar to the Barbie ${ }^{\circledR}$ doll which represents the ideal feminine slimness (Norton et al., 1996), whereas the male's point of view focuses on the robust and muscular body shape as the ideal of beauty, very similar to the super-heroes dolls male children play with (Pope et al., 1999).

A study among Brazilian adolescents in the state of Paraná, aged 15 - 19 years, verified that $48.6 \%$ of female adolescents with negative body image were eutrophic; only $2.6 \%$ of adolescents classified with malnutrition or on the malnutrition border had such disturbances; $14.5 \%$ of adolescents who had body image disturbance were actually overweight or obese. In the case of male adolescents, only $10 \%$ of the eutrophic group had body image disturbances and $8.6 \%$ were overweight or obese (Souza-Kaneshima et al., 2006; Souza-Kaneshima et al., 2008). 
When body weight awareness is higher than the body mass, the introduction of important changes in eating behaviour is enhanced. In fact, the discussion of the theme in different population segments is mandatory so that the significance of the phenomenon could be acknowledged and strategies to tackle the problem planned (Nunes et al., 2001). The development of tools to detect possible body image distortions in different population groups and the choice of such instruments are essential for the validity of the results.

Gender and ethnic groups manifest different types and degrees of body dissatisfaction. For instance, females have a higher propensity to develop body image discontent. This is due to the fact that they are constantly evaluated by society, especially with regard to their physical appearance. Even males may demonstrate body image distortions for the same reasons (Alvarez-Rayon et al., 2009; Costa et al., 2008; Cordas, 2004; Mond et al., 2004; Nunes et al., 2001).

Ethnicity-related physical characteristics also affect the adolescents' body satisfaction. A study in the state of Minnesota, USA, showed that Afro-American and mixed-race adolescents had a high body image satisfaction amounting to almost three times that in whites. On the other hand, Hispanics and Asians had the least satisfaction degree within the analyzed group (Kelly et al., 2005).

The age bracket also affects the evaluation of the body image. Young women show a higher rate of dissatisfaction as from their $13^{\text {th }}$ or $15^{\text {th }}$ year, while the male has a high degree of body image satisfaction at the same age. This is due to the fact that an increase in height and muscular mass occurs in male adolescents at this age, which brings them close to the ideal social and cultural image of the male body (Kelly et al., 2005; Raudenbush \& Zellner, 1997). Male adolescents may later have difficulties in the maintenance of their physical profile and consequently a lowering of body satisfaction levels occurs (McCabe \& Ricciardelli, 2004a).

The very first studies on this issue underscored body measurements even though social and behavioural aspects which may affect body image distortion were not taken into account. This occurred in spite of the fact that authors related gender, ethnic background and age bracket as factors that could affect body dissatisfaction.

The Body Cathexis Scale (Secord \& Jourard, 1953) was one of the first self-evaluation ratings. In 1973, Berscheid et al. developed the Body Image Questionnaire and in 1984, Winstead \& Cash introduced the Body-Self Relations Questionnaire (BSRQ). This questionnaire contains 140 items which the patients answer on a 5-point scale. Items deal with patients' attitudes and activities in three body areas: physical appearance, physical form and physical health.

The Body Attitudes Questionnaire (BAQ) (Ben-Tovim \& Walker, 1994) is a self-report questionnaire with 44 items, developed for those with concerns for body appearance, and deals with the measurement of several attitudes related to the body. Answers may be grouped into six sub-scales which describe (1) overall fatness ("Feeling fat"); (2) selfdisparagement ("Depreciation"); strength ("Strength and Physical Fitness"); (4) salience of weight ("Salience"); (5) feelings of attractiveness especially with people of the opposite sex ("Physical attraction"); (6) consciousness of lower body ("Lower limbs fatness"). High scores in the subscales "Feeling fat", "Depreciation", "Salience" and "Lower limbs fatness" produce negative attitudes with regard to the body. High scores in "Strength and Physical Fitness" and "Physical Attraction" cause positive attitudes with regard to the body.

Candy \& Fee (1998) developed the Eating Behaviours and Body Image Test (EBBIT) to identify feeding behaviour and body image in pre-adolescent girls. It is a 42 -item self-report questionnaire with four answer alternatives in which eating behaviour for each reply receives different marks. Answers range from "Most of the time" to "Never", while each 
alternative receives marks from 0 to 3 , namely, $3=$ most of the time; 2 = frequently; $1=$ rarely; $0=$ never. The test is subdivided into 3 sub-scales: (1) dissatisfaction with body image and food restriction, with 22 items; (2) compulsive eating behaviour, with 15 items; (3) 4 items for compensation behaviour associated to feeding disorders indicated by the Diagnostic and Statistical Manual of Mental Disorders (DSM IV). First and second scales are grouped for a total score and the items of the third scale are individually evaluated.

Due to their practical application and correction, the Body Shape Questionnaire (BSQ) and the Body Silhouette Figure method are currently the most quoted in the literature dealing with the evaluation of body image distortion in population studies (Mendelson et al., 2002). The Body Shape Questionnaire (BSQ) has been developed by Cooper et al. (1987) and incorporates the influence of the social milieu. It also provides an underlying evaluation of body image disorders in clinical and non-clinical populations and may be employed to evaluate the influence of body image disorders in the development, maintenance and in treatment response to feeding disturbances (Branco et al., 2006; Lemes et al., 2001; Oliveira et al., 2003). The questionnaire is composed of 34 points, each with six alternative answers, varying between "always" and "never". Marks from 1 to 6 (always $=6$; very frequent = 5; frequent $=4$; sometimes $=3$; rarely $=2$; never $=1$ ) are given to each answer. Test result is the sum of the 34 items in the questionnaire. Result classification features levels of concern with body image, or rather, less than 70 marks means normal standard and no concern with body image distortion; marks between 70 and 90 demonstrate a mild concern on body image distortion; marks between 91 and 110 mean a moderate concern with distortion; above 110 marks means a marked concern with body image distortion (Assunção et al., 2002).

Therefore, BSQ measures concerns with body form, with self-disparaging due to physical appearance and with the feeling of being 'fat'. Since it evaluates the body image's affective aspect, it is a very promising and helpful tool for the clinical follow-up of patients with eating disorders, such a bulimia nervosa (Conti, 2008; Kakeshita, 2004). Although BSQ initially evaluated the body image distortion in women with eating disorders, some studies show that it may also be used to measure concern on body form, weight and, in particular, the frequency people of both sexes, with or without eating disorder, feel that they are "fat" (Cooper et al., 1987; Freitas et al., 2002).

Other investigations evaluated BSQ in different populations without any eating disorders. Good discriminating indexes in the test's validity and reliability and its repetition, coupled to internal consistency, have been reported (Rosen et al., 1996) Although different studies may highly diverge in their dissatisfaction index with the body image, most authors agree on a high body dissatisfaction index during adolescence, mainly with the female sex, which influences the emotional (dissatisfaction) and the perceptive (high estimation) dimensions (Ferrando et al., 2002).

Almost 75\% of adolescent high school students in the state of Paraná, Brazil, aged 15 - 19, reveal a normal BMI and therefore are eutrophic subjects. Nevertheless, the BSQ questionnaire revealed that half of them had body image disorders. Moreover, a comparative analysis between the sexes verified that only $34.2 \%$ of female adolescents failed to manifest any body image disturbances. The other interviewed adolescents manifested the following degrees in image: $23.9 \%$ with mild disorders; $31.6 \%$ with moderate disorders; $10.3 \%$ with marked disorders. On the other hand, body image disorders in male adolescents were lower, featuring 11.4 and $7.2 \%$ with mild and moderate disorders respectively (SouzaKaneshima et al., 2006; Souza-Kaneshima et al., 2008). 
Predominance of body image dissatisfaction reached $15.3 \%$ among university students in Brazil (Luz, 2003). In some countries, such as Spain, body image dissatisfaction amounted to 22.1\% among female adolescents (Ferrando et al., 2002), whereas an Australian study identified body frustration in most female adolescents, aged $14-16$ years. Further, $57 \%$ of Australian young women practiced unhealthy diets and 36\% ingested anorexigenous pills, diuretics and laxatives, smoked and practiced extremely restrictive diets. The above attitudes clearly show the relationship between body dissatisfaction and abnormal behaviour, suggestive of eating disorders (Grigg et al., 1996). Moreover, a longitudinal investigation among Norwegian young women showed that body image disturbances predispose towards restrictive diets (Friestad \& Rise, 2004). Frequent diet practice may be a risk factor favouring the development of eating behaviour disorders, such as bulimia nervosa (Morgan et al., 2002).

Weight dissatisfaction in a group of female university students of the Nutrition Course in Rio de Janeiro, Brazil, was also investigated by BSQ. The slim body ideal imposed by society also prevailed in the group since $58.7 \%$ desired a decrease of two or more kilos even though their weight was adequate. A similar desire was shown by almost all the female university students with moderate and marked body image disturbances. The above result is highly relevant since body image distortion may be a risk factor for the development of eating behaviour disorders, such as bulimia nervosa. It should be emphasized that future professionals should take a different view of the patient especially in situations featuring eating disorders. Therefore, awareness of one's own body is part and parcel of the multidimensional character of eating behaviour disorders and should be discussed with future nutritionists so that society's influence in the construction process of ideas of beauty might be assessed. Consequently, their clinical attitudes would include the limits in which weight loss brings a positive impact on people's health (Bosi et al., 2006).

Silhouette Figure Body Images were introduced by Stunkard et al. (1983) with 15 silhouettes for each gender, later developed by Thompson \& Gray (1995) with a new 9-silhouette figures (Fig. 1) in individual cards containing a male and a female figure with several silhouettes. Card 1 shows a very slim person $\left(\mathrm{BMI}=12.5 \mathrm{~kg} / \mathrm{m}^{2}\right)$ and Card 9 a very obese one (IMC $\left.=47.5 \mathrm{~kg} / \mathrm{m}^{2}\right)$. The subjects choose a card with a silhouette that is closest to their body's image, identified as I; another card representing a healthy person is then chosen, identified as HEALTHY; finally, a card is chosen which represents the desired silhouette, identified as IDEAL.

Rating has five variables: 1) the number which corresponds to the current figure; 2) the number which corresponds to the healthy figure; 3) the number that corresponds to the ideal figure; 4) discrepancy scores between the healthy and current figures; and 5) discrepancy scores between the ideal and current figures. Scores range between -8 and +8 , or rather, the higher the difference, the higher the body discrepancy and, consequently, a greater dissatisfaction rate. Discrepancy scores between the healthy and current figures is a more objective rating for body dissatisfaction, whilst the discrepancy score between the ideal and current figures represents a more emotional stance (Scagliusi et al., 2006).

The Figure Body Images is a fast, easy and simple method, highly efficient in evaluating body distortion and dissatisfaction with weight and body dimensions rate. In fact, it is widely accepted and used by several researchers since it is a valid tool for quantitative studies for body image perception in both sexes (Coqueiro et al., 2008; Damasceno et al., 2005; Gardner et al., 1998; Gardner et al., 1999; Kakeshita, 2004; Madrigal et al., 2000; Tribess 

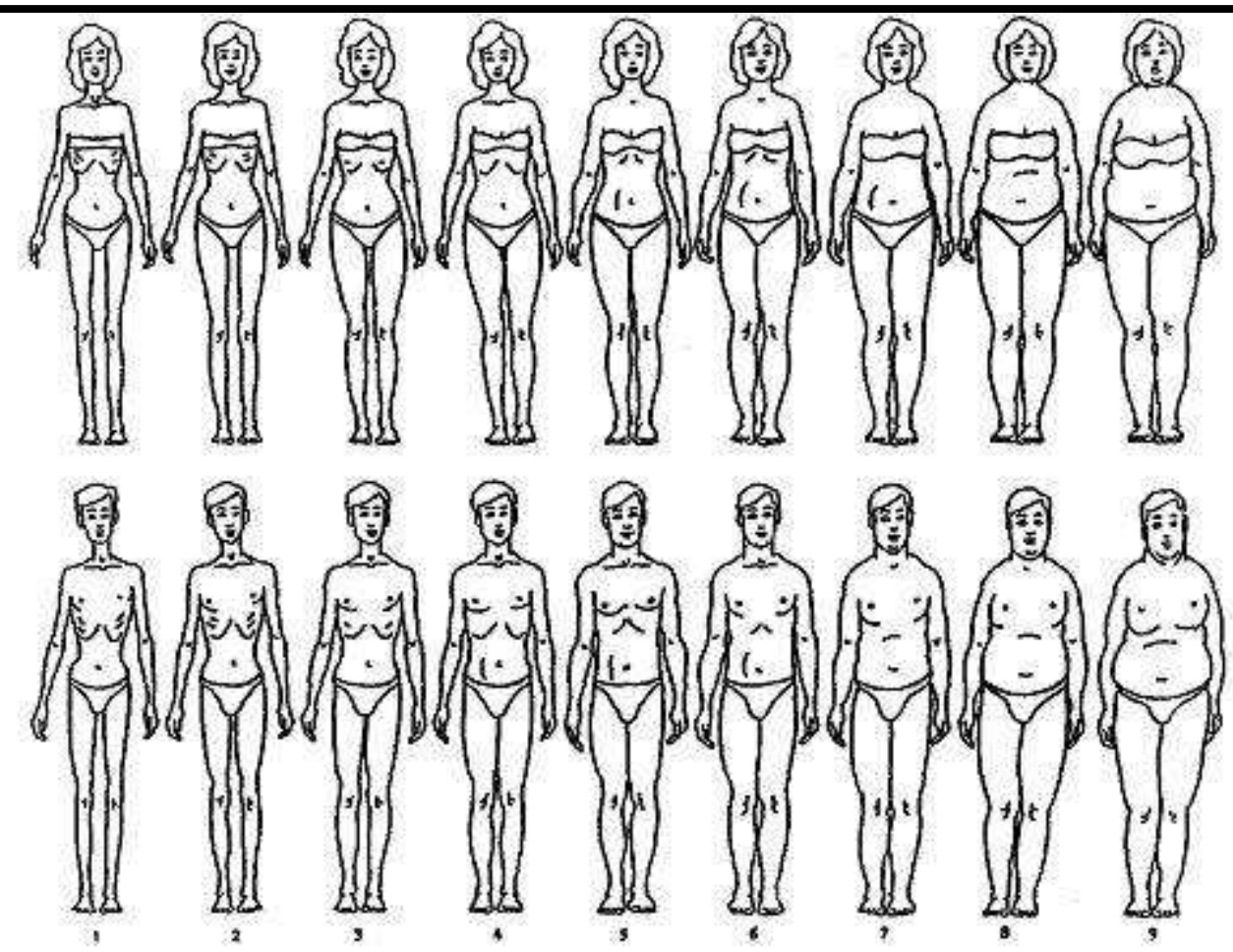

Fig. 1. Silhouette Figure Body Images developed by Stunkard et al. (1983) and modified by Thompson \& Gray (1995).

et al., 2010). However, its main limitations are the contour figures designed in a linear bidimensional form which may reproduce shortcomings in body entireness and in fat distribution (O'Brien, et al., 2007). Further, the figures may be foregrounded on biotypes which do not correspond to the characteristics of the population under analysis.

Studies employing the Figure Body Images with children aged $6-12$ years showed that in the case of girls the ideal body is substantially smaller that their own, whereas no difference in choice occurred in the case of boys (Williamson \& Delin, 2001; McCabe \& Ricciardelli, $2004 a, b)$. Owing to a more critical stance by girls with regard to their body image, they manifest a high esteem for their body image which causes a self-awareness related to overweight and obesity. Thus, girls, albeit eutrophic, choose figures with the abovementioned contours. Boys show an inverse distortion of reality, or rather, overweight boys choose figures with contours in eutrophic conditions (Branco et al., 2006)

The Figure Rating method (Stunkard et al., 1983), applied in several Brazilian studies, showed a prevalent $82 \%$ of school children dissatisfied with their body image (Erling \& Hwang, 2004; Pinheiro \& Giugliani, 2006b; Triches \& Giugliane, 2007), coupled to $78.8 \%$ of university students and physically active adults (Coqueiro et al., 2008; O'Brien et al., 2007). All these analyses report that women desire a decrease in their body contour size, whereas men desire a stronger, more muscular body. Difference in the male's and female's preference of body 
contours is due to the fact that women overestimate the body image and men underestimate it (Almeida et al., 2006; Atalah et al., 2004; Coqueiro et al., 2008; Damasceno et al., 2005; Kakeshita \& Almeida., 2006; Madrigal et al., 2000; Tanaka et al., 2002).

Although percentages of the body image dissatisfaction prevalence may be different in Australia, Croatia, UK, Mexico, Switzerland and the USA, it is very high in all countries and this lack of satisfaction is not merely found in overweight or obese subjects but also in eutrophic ones (Ricciardelli \& McCabe, 2001).

Due to incidence increase in eating disorders, such as anorexia nervosa and bulimia, several researches are relating them to body image disorders (Almeida et al., 2005; Conti et al., 2010; Killen et al., 1994; Neumark-Sztainer et al., 2006; Smolak \& Levine, 2001, Stein et al., 1998; Souza-Kaneshima et al., 2006; Souza-Kaneshima et al., 2008). It should also be underscored that during the last years body image disorders have been found in still younger eutrophic populations too (Souza-Kaneshima et al., 2006; Souza-Kaneshima et al., 2008).

\section{Consequences of body dissatisfaction}

Since body image formation involves the subjects' relationship with their own body, positive and gratifying experiences are required with regard to the body so that a satisfactory development of the body image may occur. The subjects who refuse their own physical appearance undergo an interpersonal anxiety experience and have difficulties in their social interactions (Castilho, 2001).

Overweight and obesity in any age bracket are high stigmatizing conditions in society and negatively affect the subjects' vocational, professional and relationship opportunities. Fear of being obese, body dissatisfaction and the preoccupation in being thin may establish body image distortions in children and adolescents, produce health damaging behaviour such as the inadequate ingestion of food, risking cognitive development and the development of eating behaviour disorders, such as bulimia nervosa (Cooley \& Toray, 2001; Crocker et al., 2003; Johnson \& Wardle, 2005; Nunes et al., 2003; Pinheiro \& Giugliane, 2006a; Stice et al., 2002; Vilela et al., 2004).

Girls who go on restrictive eating diets gain weight in the long run and thus a vicious circle ensues (Field et al., 2003; Stice et al., 1999; Stice et al., 2002). These situations are a source of concern to health professionals because of the high prevalence of adolescents with low body satisfaction levels (Smolak, 2004). Several studies have emphasized that body dissatisfaction is associated with eating disorders, such as anorexia nervosa and bulimia in adolescent and adult females (Cattarin \& Thompson, 1994; Thompson \& Smolack, 2001) and also in children (Gardner et al., 2002).

Several research works have associated body dissatisfaction and a wide variety of negative implication in health and behaviour, such as an increase in depression, low self-esteem, and anxiety, and an increase in dangerous habits such as smoking, alcoholism and drug-taking (Ackard et al., 2002; Granner et al., 2002; Ohring et al., 2002; Pesa et al., 2000; Rierdan \& Koff, 1997; Stice \& Shaw, 2002; Stice et al., 2000).

A five-year longitudinal study revealed that body-dissatisfied males and females frequently acquire eating compulsion, acquire bad eating behaviour, live a sedentary life and adopt unhealthy habits for weight control. The above study proved that low body dissatisfaction fails to be a motivation to get a healthy weight behaviour. On the contrary, it predisposes to types of behaviour that may put to risk adolescents' health and it increases chances in weight gaining (Neumark-Sztainer et al., 2006). 
Since most adolescents are greatly affected by social pressures, the media, parents and friends, it is recommended that their convivial milieu be focused on healthy and physical activities rather than on body weight control. This will minimize the effects of enhancements of the slim body ideal in Western society and increase the probability that they will be satisfied with their body (Kelly et al., 2005).

Several authors report that the practice of physical activity by adolescents is related to body satisfaction (Savage et al., 2009; Damasceno et al., 2005; Neumark-Sztainer et al., 2006). Parents, educators and health professionals should stimulate adolescents to adopt programs for the promotion of the healthy body and for a positive body image. This will inhibit potential damaging behaviour, such as unhealthy control in body weight and eating binges.

\section{Conclusion}

While the social media and social culture associate a beautiful body with slimness, they transmit a beauty standard unattainable by most people. The body image's distortion may be related to the thin body as the ideal body type. Since the distortion is normally linked to diseases such as depression, it may also be associated with eating disorders such as anorexia and bulimia nervosa. In fact, such diseases are difficult to deal with and perhaps the best type of prevention is an improvement of satisfaction with the body image, especially during childhood and adolescence which are the periods in which subjects are building their body image.

Educational campaigns focused on healthy social milieus which make possible an emotional well-being are highly recommended. Campaigns, physical activities and the intake of healthy food should be adopted by the community and broadcasted by all the social media. Results in the subjects' health will be visible in a short space of time. Therefore, parents, educational personnel and health agents should not merely increase their knowledge on the potential risks of overweight during childhood and its consequences in adulthood but provide practical and concrete alternatives, such as linking leisure with physical activities. It will surely improve children and adolescents' body image. The family may also provide a wide variety of healthy food for children and the latter may choose their preferences.

Children and young people will have healthy feelings with regard to themselves coupled to a solid self-esteem. They will never have their physical value tainted by the social impositions on beauty. Avoidance of eating disorders, such as bulimia nervosa, and an improvement in their body's image will be achieved when there is a change in current ideal of beauty, which is already being sustained by many experts in the field.

\section{References}

Abramovitz, B.A. \& Birch, L.L. (2000). Five-year-old girls ideas about dieting are predicted by mothers dieting. Journal of the American Dietetic Association, Vol.100, N¹0, (October 2000), pp.(1157-1163), ISSN 0002-8223.

Ackard, D.M.; Crol, L, J.K. \& Kearney-Cooke, A. (2002). Dieting frequency among college female: association with disordered eating, body image, and related psychological problems. Journal of Psychosomatic Research. Vol.52, N³, (March 2002), pp.(129-136), ISSN 0022-3999. 
Affenito, S.G. \& Kerstetter, J. (1999). Position of the American Dietetic Association and Dietitians of Canada: women's health and nutrition. Journal of the American Dietetic Association, Vol.99, N6, (June 1999), pp.738-751, ISSN 0002-8223.

Almeida G.A.N.; Santos, J.E.; Passian, S.R. \& Loureiro, S.R. (2005). Percepção de tamanho e forma corporal de mulheres: estudo exploratório. Psicologia em Estudo, Vol.10, N¹, (Janeiro/Abril 2005), pp.(27-35), ISSN 1413-7372.

Alvarez-Rayon, G.; Franco-Paredes, K.; López-Aguilar, X.; Mancilla-Díaz, J.M. \& VázquezArévalo, J. (2009). Imagen corporal y trastornos de la conducta alimentaria. Revista de Salud Pública, Vol.11, N4, (July/August 2009), pp.(568-578), ISSN 0124-0064.

Andrade, A. \& Bosi, M.L.M. (2003). Mídia e subjetividade: impacto no comportamento alimentar feminino. Revista de Nutrição, Vol.16, Nº1, (Janeiro/Março 2003), pp.(11725), ISSN 1415-5273.

Appolinário, J.C. \& Claudino, A.M. (2000). Transtornos alimentares. Revista Brasileira de Psiquiatria, Vol.22, supl.2, (Dezembro 2000), pp.(28-31), ISSN 1516-4446.

Assunção, S.S.M.; Cordas, T.A. \& Araújo, L.F.S.B. (2002). Atividade física e transtornos alimentares. Revista de Psiquiatria Clínica, Vol.29, Nº1, (Janeiro/Fevereiro 2002), pp.(4-13), ISSN 0101-6083.

Atalah, E. Urteaga, C. \& Rebolledo, A. (2004). Autopercepción del estado nutricional en adultos de Santiago. Revista Médica de Chile, Vol. 132, №11, (Novembro 2004), pp.(1383-1388), ISSN 0034-9887.

Becker, A.E.; Burwel, R.A.; Gilman, S.E.; Herzog, D.B. \& Hamburg, P. (2002). Eating Behaviours and Attitudes Following Prolonged Exposure to Television among Ethnic Fijian Adolescent Girls. The British Journal of Psychiatry, Vol.180, N6, (June 2002), pp.(509-514), ISSN 0960-5371.

Ben-Tovim, D.I. \& Walker, M.K. (1994). The influence of age and weight on women's body attitudes as measured by the Body Attitudes Questionnaire (BAQ). Journal of psychosomatic research, Vol.38, N5, (July 1994), pp.(477-481), ISSN 0022-3999.

Berscheid, E.; Walster, E. \& Bohrnstedt, G. (1973). The happy American body: A survey report. Psychology Today, Vol.7, (November 1973), pp.(119-131), ISSN 0033-3107.

Birch, L.L. \& Fisher, J.O. (1998). Development of eating behaviors among children and adolescent. Pediatric, Vol.101, N’3, (March 1998), pp.(539-549), ISSN 0031-4005.

Bosi, M.L.M.; Luiz, R.R.; Morgado, C.M.C.; Costa, M.L.S. \& Carvalho, R.J. (2006). Autopercepção da imagem corporal entre estudantes de nutrição. Jornal Brasileiro de Psiquiatria, Vol.55, N², (Abril/Junho 2006), pp.(108-113), ISSN 0047-2085.

Braet, C., Mervielde, I. \& Vandereycken, W. (1997). Psychological aspects of childhood obesity: a controlled study in a clinical and nonclinical sample. Journal of Pediatric Psychology, Vol.22, N¹1, (June 1996), pp.(59-710), ISSN 0146-8693.

Branco, L.M.; Hilário, M.O.E. \& Cintra, I.P. (2006). Percepção e satisfação corporal em adolescentes e a relação com seu estado nutricional. Revista de Psiquiatria Clínica, Vol.33, N6, (Novembro/Dezembro 2006), pp.(292-296), ISSN 0101-6083.

Candy, C.M. \& Fee, V.E. (1998). Underlying Dimensions and Psychometric Properties of the Eating Behaviors and Body Image Test for Preadolescent Girls. Journal of Clinical Child Psychology, Vol.27, N¹, (March 1998), pp.(117-127). ISSN 0047-228X.

Carvalho, A.M.P.; Cataneo, C.; Galindo, E.M.C. \& Malfara, C.T. (2005). Autoconceito e imagem corporal em crianças obesas. Paidéia, Vol.15, N³0, (Janeiro/Abril 2005), pp.(131-139), ISSN 0103-863X. 
Castilho, S.M. (Ed.). (2001). A imagem corporal, ESETec Editores Associados, ISBN 978-8588303-13-2, Santo André, SP.

Cattarin, J. \& Thompson, J.K. (1994). A three year longitudinal study of body image and eating disturbance in adolescent female. Eating Disorders: The Journal of Treatment $\mathcal{E}$ Prevention, Vol.2, N², (Sum, 1994), pp.(114-125), ISSN 1064-0266.

Conti, M.A. (2008). Os aspectos que compõem o conceito de imagem corporal pela ótica do adolescente. Revista Brasileira de Crescimento e Desenvolvimento Humano, Vol.18, N³, (Dezembro 2008), pp.(240-253), ISSN 0104-1282.

Conti, M.A.; Frutuoso, M.F.P. \& Gambardella, A.M.D. (2005a). Excesso de peso e insatisfação corporal em adolescentes. Revista de Nutrição, Vol.18, N4, (Julho/Agosto 2005), pp.(491-497), ISSN 1415-5273.

Conti, M.A; Gambardella, A.M.D. \& Frutuoso, M.F. P. (2005b). Insatisfação com a imagem corporal em adolescentes e sua relação com a maturação sexual. Revista brasileira de crescimento e desenvolvolvimento humano, Vol.15, N², (Agosto 2005), pp.(36-44), ISSN 0104-1282.

Conti, M.A.; Scagliusi, F.; Queiroz, G.K.O., Hearst, N. \& Cordás, T.A. (2010). Adaptação transcultural: tradução e validação de conteúdo para o idioma português do modelo da Tripartite Influence Scale de insatisfação corporal. Cadernos de Saúde Pública, Vol.26, N³, (March, 2010), pp.(503-513), ISSN 0104-1282.

Cooley, E. \& Toray, T. (2001). Body image and personality predictors of eating disorders symptoms during the college years. The International journal of eating disorders, Vol.30, N 1, (July 2001), pp.(28-36), ISSN 0276-3478.

Cooper, P.J.; Taylor, M.; Cooper, Z. \& Fairburn, C.G. (1987). The development and validation of the Body Shape Questionnaire. The International journal of eating disorders, Vol.6, N44, (July 1987), pp.(485-494), ISSN 0276-3478.

Coqueiro, R.S.; Petroski, E.L., Pelegrini, A., \& Barbosa, A.R. (2008). Insatisfação com a imagem corporal: avaliação comparativa da associação com estado nutricional em universitários. Revista de Psiquiatria do Rio Grande do Sul, Vol.30, N¹, (Janeiro/Abril 2008), pp.(31-38), ISSN 0101-8108.

Cordás, T.A. (2004). Transtornos alimentares: classificação e diagnóstico. Revista de Psiquiatria Clínica, Vol.31, N4, (Julho/Agosto 2004) pp.(154-157), ISSN 0101-6083.

Costa, C.; Ramos, E.; Severo, M.; Barros, H.;Lopes, C. (2008). Determinants of eating disorders symptomatology in Portuguese adolescents. Archives of pediatrics $\mathcal{E}$ adolescent medicine, Vol.162, N¹2, (December 2008), pp.(1126-1132), ISSN 1072-4710.

Crocker, P.; Sabiston, C.; Forrestor, S.; Kowalski, N.; Kowalski, K. \& McDonoug, M. (2003). Predicting change in physical activity, dietary restraint, and physique anxiety in adolescent girls: examining covariance in physical self-perceptions. Canadian journal of public health. Revue canadienne de santé publique, Vol.94, N5, (September/Octuber 2003), pp.(332-327), ISSN 0008-4263.

Crosby, R.D.; Wonderlich, S.A.; Engel, S.G.; Simonich, H.; Smyth, J. Mitchell, J.E. (2009). Daily mood patterns and bulimic behaviors in the natural environment. Behaviour Research and Therapy, Vol.47, N³, (March 2009) pp.(181-188), ISSN 0005-7967.

Cusumano, D.L. \& Thompson, J.K. (2001). Media influence and body image in 8-11-year-old boys and girls: a preliminary report on the multidimensional media influence scale. The International journal of eating disorders, Vol. 29, N¹, (January 2001); pp.(37-44), ISSN 0276-3478. 
Damasceno, V.O.; Lima, J.R.P.; Vianna, J.M.V.; Vianna, V.R.A. \& Novaes, J.S. (2005). Tipo físico ideal e satisfação com a imagem corporal de praticantes de caminhada. Revista Brasileira de Medicina do Esporte, Vol.11, N³, (Maio/Junho 2005), pp.(181186), ISSN 1517-8692.

Davison, K.K.; Markey, C.N. \& Birch, L.L. (2000). Etiology of body dissatisfaction and weight concerns among 5-year-old girls. Appetite, Vol.35, N², (October 2000), pp.(143-151), ISSN 0195-6663.

Davison, K.K. \& Birch, L.L. (2001). Weight status, parent reaction, and self-concept in fiveyear-old girls. Pediatrics, Vol.107, N¹, (January 2001), pp.(46-53), ISSN 0031-4005.

Duquin, M.E. (1989). Fashion and fitness: Images in women's magazine advertisement. Arena Review, Vol.13, N², (December 1989), pp. (97-109), ISSN 0735-1267.

Erling, A. \& Hwang, C. (2004). Body-esteem in Swedish 10-year-old children. Perceptual and motor skills, Vol. 99, N², (Octuber 2004), pp.(437-444), ISSN 0031-5125.

Ferrando, D.B.; Blanco, M.G.; Masó, J.P.; Gurnés, C.S. \& Avellí, M.F. (2002). Eating attitudes and body satisfactions in adolescents: a prevalence study. Actas españolas de psiquiatria, Vol.30, N4, (July/August 2002), pp.(207-212), ISSN 1139-9287.

Ferriani, M.G.C.; Dias, T.S.; Silva, K.Z. \& Martins, C.S. (2005). Autoimagem corporal de adolescentes atendidos em um programa multidisciplinar de assistência ao adolescente obeso. Revista Brasileira de Saúde Materno-Infantil, Vol.5, N¹, (Janeiro/Março 2005), pp. (27-33), ISSN 1519-3829.

Field, A.E.; Austin, S.B.; Taylor, C.B. Malspeis, S.; Rosner, B.; Rockett, H.R.; Gillman, M.W. \& Colditz, G.A. (2003). Relation between dieting and weight change among preadolesce and adolescents. Pediatrics, Vol.112, N4, (October 2003), pp.(900-906), ISSN 0031-4005.

Finger, C. (2003). Brazilian beauty. Lancet, Vol.362, N9395, p.1560, ISSN 0140-6736.

Fonseca, H. \& Matos, M.G. (2005). Perception of overweight and obesity among Portuguese adolescents: an overview of associated factors. European Journal of Public Health, Vol.15, N³, (June 2005), pp.(323-328), ISSN 1101-1262.

Freitas, S.; Gorenstein, C. \& Appolinario, J.C. (2002). Instrumentos para a avaliação dos transtornos alimentares. Revista Brasileira Psiquiatria, Vol.24, N’3, (December 2002), pp.(34-8), ISSN 1516-4446.

Friestad, C. \& Rise, J. (2004). A longitudinal study of the relationship between body image, self-esteem and dieting among 15-21 year olds in Norway. European eating disorders review, Vol.12 N4, (July/August 2004), pp.(247-255), ISSN 1072-4133.

Gardner. R.M.; Friedman, B.N. \& Jackson, N.A. (1998). Methodological concerns when using silhouettes to measure body image. Perceptual and motor skills, Vol.86, N², (April 1998), pp.(387-395), ISSN 0031-5125.

Gardner, R.M.; Stark, K.; Jackson, N.A. \& Friedman, B.N. (1999). Development and validation of two new scales for assessment of body image. Perceptual and motor skills, Vol.89, N³ (December1999), pp.(981-993), ISSN 0031-5125.

Gardner, R.M.; Stark, K.; Friedman, B.N. \& Jackson, N.A. (2002. Predictors of eating disorders scores in children ages 6 through 14: a longitudinal study. Journal of psychosomatic research, Vol. 49, N³, (September 2002), pp.(199-205), ISSN 0022-3999.

Gleaves, D.H.; Williamson, D.A.; Eberenz, K.P.; Sebastian, S.B. \& Barker, S.E. (1995). Clarifying body image disturbance: Analysis of a multidimensional model using 
structural modeling. Journal of Personality Assessment, Vol.64, N³, (June 1995) pp.(478-493), ISSN 0022-3891.

Granner, M.L.; Black, D.R. \& Abood, D.A. (2002). Levels of cigarette and alcohol use related to eating-disorder attitude. American journal of health behavior, Vol.26, N¹, (February 2002), pp.(43-55), ISSN 1087-3244.

Grigg, M.; Bowman, J. \& Redman, S. (1996). Disordered eating and unhealthy weight reduction practices among adolescent females. Preventive medicine, Vol.25, No6 (November/December 1996), pp. (748-756), ISSN 0091-7435.

Grillo, E. \& Silva, R.J.M. (2004). Early manifestations of behavioral disorders in children and adolescents. Jornal de Pediatria, Vol.80, N², (Abril 2004), pp.(21-27), ISSN 0021-7557.

Gucciardi, E.; Celasun, N.; Ahmad, F., Stewart, D.E. (2004). Eating disorders. BMC Women's Health, Vol.4, suppl.1, (August 2004) pp. (S21), ISSN 1472-6874.

Heinberg, L.J. \& Thompson, J.K. (1992). Social comparison: gender, target importance rating, and relation to body-image disturbance. Journal of social behavior and personality, Vol.7, N², pp.(335-344), ISSN 0886-1641.

Hesse-Biber, S.; Clayton-Matthews, A. \& Downey, J.A. (1987). The differential importance of weight and body-image among college men and women. Genetic, social, and general psychology monographs. Vol.113, N4, (November 1987), pp.(509-528), ISSN 87567547.

Hill, A.J. \& Franklin, J.A. (1998). Mothers, daughters, and dieting: investigating the transmission of weight control. The British journal of clinical psychology, Vol.37, $\mathrm{N}^{\circ} 1$, (February 1998), pp.(3-13), ISSN 0144-6657.

Irving, L.M. (1990). Mirror images: Effects of the standard of beauty on the self and bodyesteem of women exhibiting varying levels of bulimic symptoms. Journal of social and clinical psychology, Vol.9, N², pp.(230-242), ISSN 0736-7236.

Jauregui-Lobera, I., Polo, I.M., González, M.T. \& Millán, M.T. (2008). Percepción de La obesidad em jóvenes universitários y pacientes com trastornos de la conducta alimentaria. Nutrición hospitalaria Vol. 23, N³, (May/June 2008), pp. (226-233), ISSN 0212-1611.

Johnson, F. \& Wardle, J. (2005). Dietary restraint, body dissatisfaction, and psychological distress: a prospective analysis. Journal of abnormal psychology, Vol.114, $\mathrm{N}^{\circ} 1$, (February 2005), pp.(119-125), ISSN 0021-843X.

Kakeshita, I.S. \& Almeida, S.S. (2006). Relação entre índice de massa corporal e a percepção da auto-imagem em universitários. Revista de Saúde Pública, Vol.40, N³, (Junho 2006), pp.(497-504), ISSN 0034-8410.

Kakeshita, I.S. (2004). Estudo das relações entre o estado nutricional, a percepção da imagem corporal e o comportamento alimentar em adultos. [Master's dissertation]. Ribeirão Preto: Faculdade de Filosofia, Ciências e Letras - USP.

Kaufman, A. (2000). Transtornos alimentares na adolescência. Revista Brasileira de Medicina, Vol.57, N¹, (Janeiro 2000), pp.(8), ISSN 0034-7264.

Keel, P.K.; Heatherton, T.F.; Harnden, J.L. \& Hornig, C.D. (1997). Mothers, fathers, and daughters: dieting and disordered eating. Eating disorders: The Journal of Treatment $\mathcal{E}$ Prevention, Vol.5, N³, pp.(216-228), ISSN 1064-0266

Kelly, A. M., Wall, M., Eisenberg, M. E., Story, M. \& Neumark-Sztainer, D. (2005). Adolescent girls with high body satisfaction: Who are they and what can they teach 
us? Journal of adolescent health care, Vol.37, N5, (November 2005), pp.(391-396). ISSN 0197-0070.

Killen, J.D.; Taylor, C.B.; Halyward, C.; Wilson, D.M.; Haydel, K.F.; Hammer, L.D.; Simmonds, B.; Robinson, T. N.; Litt, I.; Varady, A.. \& Kraemer, H. (1994). Persuit of thinness and onset of eating disorder symptom in a community sample of adolescent girls: a three-year prospective analysis. The International journal of eating disorders, Vol.16, N³, (November 1994), pp.(227-238), ISSN 0276-3478.

Kjelsas, E., Bjornstrom, C. \& Gotestam, K.G. (2004). Prevalence of eating disorders in female and male adolescents (14-15 years). Eating behaviors, Vol.5, N¹, (January 2004), pp.(13-25), ISSN 1471-0153.

Lattimore, P.J. \& Butterworth, M. (1999). A test of the structural model of initiation of dieting among adolescent girls. Journal of psychosomatic research, Vol.46, №3, (March 1999), pp.(295-299), ISSN 0022-3999.

Lemes, S.O.; Valverde, M.A.; Fisberg, P.I.P. \& Franques, A.M. (2001). Percepção de imagem corporal em adultos (obesos e sobrepeso) do "Spa Médico São Pedro/Sorocaba$\mathrm{SP}^{\prime \prime}$. A Folha Medica, Vol.120, N4, (Outubro/Dezembro 2001), pp.(229-234), ISSN 0015-5454.

Leonhard, M.L. \& Barry, N.J. (1998). Body image and obesity: effects of gender and weight on perceptual measures of body image. Addictive behaviors. Vol.23, $\mathrm{N}^{\circ} 1$, (January/February 1998), pp.(31-34). ISSN 0306-4603.

Lowes, J. \& Tiggemann, M. (2003). Body dissatisfaction, dieting awareness and the impact of parental influence in young children. British journal of health psychology, Vol.8, No2, (May 2003), pp.(135-47), ISSN 1359-107X.

Luz, S.S. (2003). Avaliação de sintomas de transtornos alimentares em universitários de Belo Horizonte [Master's dissertation]. São Paulo: Faculdade de Ciências Farmacêuticas, Universidade de São Paulo.

Madrigal, H.; Sanches-Villegas, A.; Martinez-Gonzalez, M.A.; Kearney, J.; Gibney, M.J.; Irala, J. \& Martinez, J.Á. (2000). Underestimation of body index through perceived body image as compared to self-reported body mass index in the European Union. Public Health Vol.114, N6, (November 2000), pp.(468-473), ISSN 0033-3506.

Martin, M.C. \& Kennedy, P.F. (1993). Advertising and social comparison: Consequences for female preadolescents and adolescents. Psychology and Marketing, Vol.10, N6, (November/December 1993), pp.(513-30), ISSN 1520-6793.

McCabe, M. P., \& Ricciardelli, L. A. (2004a). Body image dissatisfaction among males across the lifespan: a review of past literature. Journal of Psychosomatic Research, Vol.56, N6, (June 2004), pp.(675-685), ISSN 0022-3999.

McCabe, M. P., \& Ricciardelli, L. A. (2004b). Longitudinal study of pubertal timing and extreme body change behaviors among adolescent boys and girls. Adolescence, Vol.39, N¹53, pp.(145-166), ISSN 0001-8449.

Mendelson, B.K.; McLaren, L.; Gauvin, L. \& Steiger, H. (2002). The relationship of selfesteem and body esteem in women with and without eating disorders. The International Journal of Eating Disorders, Vol.31, N³, (April 2002), pp.(318-323), ISSN 0276-3478.

Miranda, M.R. (2000). Anorexia nervosa e bulimia à luz da psicanálise - a complexidade da relação mãe-filha. Pediatria Moderna, Vol.36, N 6, (Novembro/Dezembro 2000), pp.(396-401), ISSN 0031-3920. 
Mond, J.M., Hay, P.J., Rodgers, B., Owen, C. \& Beumont, P.J. (2004). Beliefs of women concerning causes and risk factors for bulimia nervosa. The Australian and New Zealand journal of psychiatry, Vol.38, N6, (June 2004) pp.(463-469), ISSN 0004-8674.

Morgan, C.M.; Vecchiatti, I.R. \& Negrão, A.B. (2002). Etiologia dos transtornos alimentares: aspectos biológicos, psicológicos e socioculturais. Revista Brasileira de Psiquiatria, Vol.24, Supl3, (Dezembro 2002), pp.(18-23), ISSN 1516-4446.

Morrison, T.G.; Kalin, R. \& Morrison, M.A. (2004). Body-image evaluation and body-image investment among adolescents: A test of sociocultural and social comparison theories. Adolescence, Vol.39, N¹55, (Fall 2004), pp.(571-592), ISSN 0001-8449.

Mukai, T. (1996). Mothers, peers, and perceived pressure to diet among Japanese adolescent girls. Journal of research on adolescent, Vol.6, N’3, pp.(309-324), ISSN 1050-8392.

Murray, S.H.; Touyz, S.W. \& Beumont, P.J.V. (1996). Awareness and perceived influence of body ideals in media: A comparison of eating disorder patients and the general community. Eating disorders: A Journal of Treatment and Prevention, Vol.4, N¹, pp.(33-46). ISSN 1064-0266.

Neumark-Sztainer, D.; Paxton, S.J.; Hannan, P.J.; STAT, M.; Haines, J. \& Story, M. (2006). Does body satisfaction matter? Five-year longitudinal associations between body satisfaction and health behaviors in adolescent females and males. The Journal of adolescent health, Vol.39, №2 (August 2006), pp.(244-251), ISSN 1054-139X.

Norton, R.; Olds, T.; Olive, S. \& Dank, S. (1996). Ken and Barbie at life size. Sex Roles, Vol.34, N³-4 (February 1996), pp.(287-294). ISSN 0360-0025.

Nunes, M.A.; Olinto, M.T.A.; Barrosa, F.C. \& Camey, S. (2001). Influência da percepção do peso e do índice de massa corporal nos comportamentos alimentares anormais. Revista Brasileira de Psiquiatria, Vol.23, N¹, (Março 2001), pp.21-27, ISSN 1516-4446.

Nunes, M.A.; Barros, F.C.; Olinto, M.T.A.; Camey, S. \& Mari, J.D. (2003). Prevalence of abnormal eating behaviors and inappropiate methods of weight control in young women from Brazil: a population-based study. Eating and weight disorders, Vol.8, $\mathrm{N}^{\circ} 2$, (June 2003), pp.(100-106), ISSN 1124-4909.

O’Brien, K.; Venn, B.J.; Perry, T.; Green, T.J.; Aitken, W.; Bradshaw, A. \& Thomson, R. (2007). Reasons for wanting to lose weight: different strokes for different folks. Eating Behaviors, Vol.8, N¹1, (January 2007), pp.(132-135), ISSN 1471-0153.

O'Koon, J. (1997). Attachment to parents and peers in late adolescence and their relationship with self image. Adolescence, Vol.32, N¹26, pp.(471-482), ISSN 0001-8449.

Ogden, J. \& Thomas, D. (1999). The role of familial values in understanding the impact of social class on weight concern. The International journal of eating disorders, Vol.25, N³, (April 1999), pp.(273-279), ISSN 0276-3478.

Ohring, R.; Graber, J.A. \& Brooks-Gunn, J. (2002). Girls' recurrent and concurrent body dissatisfaction: correlates and consequences over 8 years. The International journal of eating disorders, Vol.31, N4, (May 2002), pp.(404-415), ISSN 0276-3478.

Oliveira, F.P.; Bosi, M.L.M.; Vigário O.S.; Vieira, R.S. (2003). Comportamento alimentar e imagem corporal em atletas. Revista Brasileira de Medicina e Esporte, Vol.9, №6 (Novembro/Dezembro 2003), pp.(348-356), ISSN 1517-8692.

Paxton, S. J.; Wertheim, E. H.; Gibbons, K.; Szmukler, G. I.; Hillier, L. \& Petrovich, J. L. (1991). Body image satisfaction, dieting beliefs, and weight loss behaviors in adolescent girls and boys. Journal of Youth and Adolescence, Vol.20, N³, (June 1991), pp.(161-379), ISSN 0047-2891. 
Pedrinola, F. (2002) Nutrição e transtornos alimentares na adolescência. Pediatria Moderna, Vol.38, N8, (Agosto 2002), pp.(377-380), ISSN 0031-3920.

Pesa, J.A.; Syre, T.R. \& Jones, E. (2000). Psychosocial differences associated with body weight among female adolescents: the importance of body image. The Journal of adolescent health. Vol.26, N5, (May 2000), pp.(330-337), ISSN 1054-139X.

Petrie, T.A.; Austin, L.J.; Crowley, B.J.; Helmcamp, A.; Johnson C.E.; Lester, R.; Rogers, R.; Turner, J. \& Walbrick, K. (1996). Sociocultural expectations of attractiveness for males. Sex Roles, Vol.35, N9-10, (November 1996), pp.(581-602), ISSN 0360-0025.

Pinheiro, A.P. (2003). Insatisfação com o corpo, auto-estima e preocupações com o peso em escolares de 8 a 11 anos de Porto Alegre [Master's dissertation]. Porto Alegre: Universidade Federal do Rio Grande do Sul.

Pinheiro, A.P. \& Giugliani, E.R.J. (2006a) Quem são as crianças que se sentem gordas apesar de terem peso adequado? Jornal de Pediatria, Vol.82, N³, (Maio/Junho 2006), pp.(232-235), ISSN 0021-7557.

Pinheiro, A.P. \& Giugliani, E.R. (2006b). Body dissatisfaction in Brazilian schoolchildren: prevalence and associated factors. Revista de Saude Publica, Vol.40, N`3, (June 2006), pp.(489-496), ISSN 0034-8910.

Pope, H.G.; Olivardia, R.; Gruber, A. \& Borowiescki, J. (1999). Evolving ideals of male body image as seen through action toys. The International journal of eating disorders. Vol.26, N¹, (July 1999), pp.(65-72), ISSN 0276-3478.

Raudenbush, B. \& Zellner, D.A. (1997). Nobody's satisfied: effect of abnormal eating behaviors and perceived and actual weight status on body image satisfaction in males and females. Journal of social and clinical psychology, Vol.16, N¹, (Spring 1997), pp.(95-110), ISSN 0736-7236.

Reato, L.F.N.; Azevedo, M.R.D.; Nogueira, F.C.; Ribeiro, C. \& Souza, S. (2000). Distúrbio alimentar em adolescente. Sinopse de Pediatria, Vol.6, N³, (Setembro 2000), pp.(6972), ISSN 0100-9281.

Reato, L.F.N. (2002). Imagem corporal na adolescência e meios de comunicação. Pediatria Moderna, Vol.38, N8, (Agosto 2002), pp.(362-366), ISSN 0031-3920.

Ricciardelli, L.A.; Mccabe, M.P. \& Banfield, S. (2000). Body image and body change methods in adolescent boys: a role of parents, friends, and the media. Journal of psychosomatic research, Vol.49 N³, (September 2000), pp.(189-197), ISSN 0022-3999.

Ricciardelli, L.A. \& McCabe, M. (2001). Children's body image concerns and eating disturbance: a review of the literature. Clinical psychology review, Vol.21, N³, (April 2001), pp.(325-344), ISSN 0272-7358.

Rierdan, J. \& Koff, E. (1997). Weight, weight-related aspects of body image and depression in early adolescent girls. Adolescence, Vol.32, Nº127, (Fall 1997), pp.(615-624), ISSN 0001-8449.

Robinson, T.N. (2001). Television viewing and childhood obesity. Pediatric clinics of North America, Vol.48, N4, (August 2001), pp.(1017-1025), ISSN 0031-3955.

Robinson, T.N.; Chang, J.Y.; Haydel, K.F. \& Killen, J.D. (2001). Overweight concerns and body dissatisfaction among third-grade children: the impacts of ethnicity and socioeconomic status. The Journal of pediatrics. Vol.138, N`2, (February 2001), pp.(181-187), ISSN 0022-3476. 
Rodin, J.; Silberstein, L. \& Striegel-Moore, R. (1985) Women and weight: a normative discontent. In: Psychology and gender, Sonderegger, T.B. (Ed), pp.267-307, University of Nebraska Press, ISBN 0803291507, Lincoln, NE.

Rosen, J.C.; Jones, A.; Ramirez, E. \& Waxman, S. (1996). Body shape questionnaire: studies of validity and reliability. The International journal of eating disorders, Vol.20, N³, (November 1996), pp.(315-319), ISSN 0276-3478.

Saikali, C.J.; Soubhia, C.S.; Scalfaro, B.M. \& Cordás TA. (2004). Imagem corporal nos transtornos alimentares. Revista de Psiquiatria Clínica, Vol.31, N4, (Julho/Agosto 2004), pp.(154-156), ISSN 0101-6083.

Sands, E.R. \& Wardle, J. (2003). Internalization of ideal body shapes in 9-12-year-old girls. The International journal of eating disorders., Vol.33, N², (March 2003), pp.(193-204), ISSN 0276-3478.

Savage, J. S.; Dinallo, J. M. \& Downs, D. S. (2009). Adolescent body satisfaction: the role of perceived parental encouragement for physical activity. The International Journal of Behavioral Nutrition and Physical Activity, Vol.6, N90, Published online 2009 December 9. doi: 10.1186/1479-5868-6-90, ISSN 1479-5868.

Scagliusi, F.B.; Polacow, V.O.; Cordas, T.A.; Coelho, D.; Alvarenga, M.; Philippi, S.T. \& Lancha Junior, A.H. (2006). Tradução, adaptação e avaliação psicométrica da Escala de Conhecimento Nutricional do National Health Interview Survey Câncer Epidemiology. Revista de Nutrição, Vol.19, N4, (Julho/Agosto 2006), pp.(425-436), ISSN 1415-5273.

Schwartz, M.B. \& Brownell, K.D. (2004). Obesity and body image. Body Image, Vol.1, N¹, (January 2004), pp.(43-56), ISSN 1740-1445

Secord, P. F. \& Jourard, S. M. (1953). The appraisal of body cathexis: body-cathexis and the self. Journal of Consulting Phychology. Vol.17, N5, (Octuber 1953), pp.(343-347), ISSN 0095-8891.

Silva, C.G.; Teixeira, A.S. \& Goldberg, T.B.L. (2003). O esporte e suas implicações na saúde óssea de atletas adolescentes. Revista Brasileira de Medicina do Esporte, Vol.9, N6, (November/December 2003), pp.(426-432), ISSN 1517-8692.

Silverstein, B.; Perdue, L.; Peterson, B. \& Kelly, E. (1986). The role of the mass media in promoting a thin standard of bodily attractiveness for women. Sex Roles, Vol.14, N9-10, (May 1986), pp.(519-33), ISSN 0360-0025.

Smolak, L. (2004). Body image in children and adolescents: Where do we go from here? Body Image, Vol.1, N¹, (January 2004), pp.15-28, ISSN 1740-1445.

Smolak, L.; Levine, M.P. \& Schermer, F. (1999). Parental input and weight concerns among elementary school children. The International journal of eating disorders, Vol.25, $\mathrm{N}^{\circ} 3$, (April 1999), pp.(263-271), ISSN 0276-3478.

Smolak, L. \& Levine, M.P. (2001). Body image in children. In: Body image, eating disorders and obesity in youth: assessment, prevention and treatment. Thompson JK, Smolak L, (Eds.), pp.41-66, American Psychological Association, ISBN 978-1-55798-758-7, Washington (DC).

Sommers-Flanagan, R.; Sommers-Flanagan, J. \& Davis, B. (1993). What's happening on music television? A gender role content analyses. Sex Roles, Vol.28, No11-12, (June 1993), pp.745-53, ISSN 0360-0025.

Souza-Kaneshima, A.M.; França, A.A.; Kneube, D.P.F. \& Kaneshima, E.N. (2006). Ocorrência de anorexia nervosa e distúrbio de imagem corporal em estudantes do ensino 
médio de uma escola da rede pública da cidade de Maringá, Estado do Paraná. Acta Scientiarum Health Sciences, Vol.28, N², (Julho/Dezembro 2006), pp.(119-127), ISSN 1679-9291.

Souza-Kaneshima, A.M.; França, A.A.; Kneube, D.P.F. \& Kaneshima, E.N. (2008). Identificação de distúrbios da imagem corporal e comportamentos favoráveis ao desenvolvimento da bulimia nervosa em adolescentes de uma Escola Pública do Ensino Médio de Maringá, Estado do Paraná. Acta Scientiarum Health Sciences, Vol.30, N², (Julho/Dezembro 2008), pp.(167-173), ISSN 1679-9291.

Stein, S.; Chalhoub, N. \& Hodes, M. (1998). Very early-onset bulimia nervosa: report of two cases. The International journal of eating disorders. Vol.24, ํo3, (November 1998), pp.(323-327), ISSN 0276-3478.

Stettler, N. (2004). Comment the global epidemic of childhood obesity: is there a role for the paediatrician? Obesity reviews, Vol.5; N 1, (May 2004), pp.(1-3), ISSN 1467-7881.

Stice, E.; Schupak-Neuberg, E.; Shaw, H.E. \& Stein, R.I. (1994). Relation of media exposure to eating disorder symptomatology: An examination of mediating mechanisms. Journal of Abnormal Psychology, Vol.103, N4, pp.(836-840), ISSN 0021-843X.

Stice, E.; Nemeroff, C. \& Shaw, H.E. (1996). Test of the dual pathway model of bulimia nervosa: Evidence of dietary restraint and affect regulation mechanism. Journal of Social and Clinical Psychology. Vol.15, N³, (Fall 1996), pp.(340-363), ISSN 0736-7236.

Stice, E.; Cameron, R.P.; Killen, J.D.; Hayward C. \& Taylor, C.B. (1999). Naturalistic weightreduction efforts prospectively predict growth in relative weight and onset of obesity among female adolescents. Journal of consulting and clinical psychology, Vol.67, N6, (December 1999), pp.(967-674), ISSN 0022-006X.

Stice, E.; Hayward, C.; Cameron, R.; Killen, J. \& Taylor, C. (2000). Body image and eating disturbances predict onset of depression among female adolescents: a longitudinal study. Journal of Abnormal Psychology, Vol.109, №3, (August 2000), pp.(438-444), ISSN 0021-843X.

Stice, E.; Presnell, K. \& Spangler, D. (2002). Risk factors for binge eating onset in adolescent girls: a 2-years prospective investigation. Health psychology, Vol.21, N², (March 2002), pp.(131-138), ISSN 0278-6133.

Stice, E. \& Whitenton, K. (2002). Risk factors for body dissatisfaction in adolescent girls: a longitudinal investigation. Developmental psychology, Vol.38, №5, (September 2002), pp.(669-678), ISSN 0012-1649.

Stice, E. \& Shaw, H.E. (2002). Role of body dissatisfaction in the onset and maintenance of eating pathology: a synthesis of research findings. Journal of psychosomatic research, Vol.53, No5, (November 2002), pp.(985-993), ISSN 0022-3999.

Stormer, S.M. \& Thompson, J.K. (1996). Explanations of body image disturbance: A test of maturational status, negative verbal commentary, social comparison, and sociocultural hypotheses. The International journal of eating disorders, Vol.19, N², (March 1996), pp.(193-202), ISSN: 0276-3478.

Striegel-Moore, R. (2001). Body image concerns among children. The Journal of pediatrics, Vol.138, N², (February 2001), pp.(158-160), ISSN 0022-3476.

Striegel-Moore, R.H.; Schreiber, G.; LO, A.; Crawford, P.B.; Obarzanek, E. \& Rodin, J. (2000). Eating disorder symptoms in a sample of 11 to 16 year-old black girls and white girls: The NHLBI growth and health study. The International journal of eating disorders, Vol.27, Nº1, (January 2000), pp.(49-66), ISSN 0276-3478. 
Stunkard, A.J.; Sorenson, T. \& Schlusinger, F. (1983). Use of the Danish adoption register for the study of obesity and thinness, In: Genetics of neurological and psychiatric disorders, Kety, S.S.; Rowland, L.P.; Sidman, R.L. \& Matthysse, S.W., pp 115-120, Raven Press, ISBN 0890046263, New York.

Tanaka, S.; Itoh, Y. \& Hattori, K. (2002). Relationship of body composition to body-fatness estimation in Japanese university students. Obesity research, Vol.10, N7, (July 2002), pp.(590-596), ISSN 1071-7323.

Tavares, M.C.G.C. (2003). Imagem corporal: conceito e desenvolvimento. Editora Manole, ISBN 8520416373, Barueri-SP.

Taylor, C.B.; Sharpe, T.; Shisstak, C.; Byrson, S.; Estes, L.S. \& Gray, N. (1998). Factors associated with weight concerns in adolescent girls. The International journal of eating disorders, Vol.24, N¹, (July 1998), pp.(31-42), ISSN 0276-3478.

Thompson, M.A. \& Gray, J.J. (1995). Development and validation of a new body-image assessment scale. Journal of personality assessment, Vol.64, N², (April 1995), pp.(258269), ISSN 0022-3891.

Thompson, A.M. \& Chad, K.E. (2000). The relationship of pubertal status to body image, social physique anxiety, preoccupation with weight and nutritional status in young females. Canadian journal of public health, Vol.91, N³, (May/June 2000), pp.(207211), ISSN 0008-4263.

Thompson, J.K. \& Smolak, L. (2001). Body image, eating disorders and obesity in youth: assessment, prevention, and treatment, American Psychological Association, ISBN 9781-55798-758-7 Washington (DC).

Thornton, B. \& Moore, S. (1993). Physical attractiveness contrast effect: Implications for selfesteem and evaluations of the social self. Personality $\mathcal{E}$ social psychology bulletin, Vol.19, N4, (August 1993), pp.(474-480), ISSN 0146-1672.

Tiggemann, M. (1994). Gender differences in the interrelationships between weight dissatisfaction, restraint, and self esteem. Sex Roles, Vol.30, N5-6, (March 1994), pp.(319-330), ISSN 0360-0025.

Tribess, S.; Virtuoso Junior, J. S. \& Petroski, E. L. (2010). Estado nutricional e percepção da imagem corporal de mulheres idosas residentes no nordeste do Brasil. Ciência $\mathcal{E}$ Saúde Coletiva, Vol.15, N¹, (Janeiro 2010), pp.(31-38), ISSN 1413-8123.

Triches, R.M. \& Giugliani, E.R.J. (2007). Insatisfação corporal em escolares de dois municípios da região Sul do Brasil. Revista de Nutrição, Vol.20, N², (Março/Abril 2007), pp.(119-128), ISSN 1415-5273.

Vigarello, G. (Ed.). (2006). História da beleza: o corpo e a arte de se embelezar, do Renascimento aos dias de hoje, Ediouro, ISBN 8500018666, Rio de Janeiro, RJ.

Vilela, J.E.; Lamounier, J.A.; Dellaretti Filho, M.A.; Barros Neto, J.R. \& Horta, G.M. (2004). Eating disorders in school children. Jornal de Pediatria. Vol.80, $\mathrm{N}^{\circ} 1$, (January/February. 2004), pp.(49-54), ISSN 0021-7557.

Wang, Z.; Byrne, N.M.; Kenardy, J.A. \& Hills, A.P. (2005). Influences of ethnicity and socioeconomic status on the body dissatisfaction and eating behaviour of Australian children and adolescents. Eating Behaviors. Vol.6, №1, (January 2005), pp.(23-33), ISSN 1471-0153.

Wardle, J. \& Cooke, L. (2005). The impact of obesity on psychological well-being. Best practice $\mathcal{E}$ research: Clinical endocrinology \& metabolism. Vol.19, N³, (September 2005), pp.(421-440), ISSN 1521-690X. 
Wheeler, L. \& Miyake, K. (1992). Social comparison in everyday life. Journal of Personality and Social Psychology, Vol.62, N5, (May 1992), pp.(760-773), ISSN 0022-3514.

Wichstrom, L. (1995). Social, psychological and physical correlates of eating problems: a study of the general adolescent population in Norway. Psychological medicine, Vol.25, N³, (May 1995), pp.(567-579), ISSN 0033-2917.

Williamson, S. \& Delin, C. (2001). Young children's figural selections: accuracy of reporting and body size dissatisfaction. The International journal of eating disorders, Vol.29, N¹, (January 2001), pp.(80-84), ISSN 0276-3478.

Winstead, B.A., \& Cash, T.F. (1984, March). Reliability and validity of the Body-Self Relations Questionnaire. Paper presented at the annual meeting of the Southeastern Psychological Association, New Orleans, LA. 


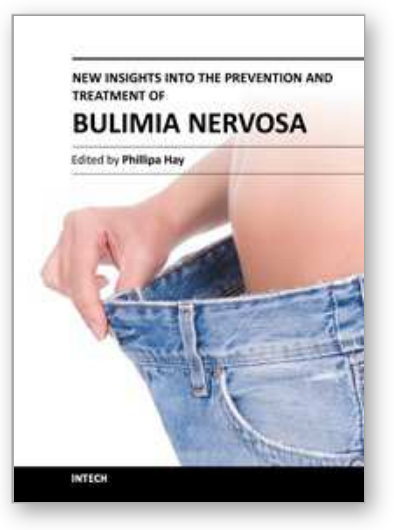

\author{
New Insights into the Prevention and Treatment of Bulimia Nervosa \\ Edited by Prof. Phillipa Hay
}

ISBN 978-953-307-767-3

Hard cover, 190 pages

Publisher InTech

Published online 03, October, 2011

Published in print edition October, 2011

Bulimia nervosa and eating disorders are common cause of distress and health related burden for young women and men. Despite major advances over the past three decades many patients come late to treatment and find that the therapy is incompletely addressed to the complex psychopathology and co-morbidities of the illness. The present book brings timely and contemporary understandings of bulimia nervosa to aid in current thinking regarding prevention and treatment. It will be read by therapists interested in enhancing their current approaches and those interested in earlier and more effective prevention and closing the gap between illness onset and accessing treatment. They will find practical guidance but also new ideas and ways of thinking about bulimia nervosa and the illness experience in this book.

\title{
How to reference
}

In order to correctly reference this scholarly work, feel free to copy and paste the following:

Alice Maria de Souza-Kaneshima and Edilson Nobuyoshi Kaneshima (2011). Bulimia Nervosa and Dissatisfaction of Adolescent's Body Shape, New Insights into the Prevention and Treatment of Bulimia Nervosa, Prof. Phillipa Hay (Ed.), ISBN: 978-953-307-767-3, InTech, Available from:

http://www.intechopen.com/books/new-insights-into-the-prevention-and-treatment-of-bulimia-nervosa/bulimianervosa-and-dissatisfaction-of-adolescent-s-body-shape

\section{INTECH}

open science | open minds

\author{
InTech Europe \\ University Campus STeP Ri \\ Slavka Krautzeka 83/A \\ 51000 Rijeka, Croatia \\ Phone: +385 (51) 770447 \\ Fax: +385 (51) 686166 \\ www.intechopen.com
}

\author{
InTech China \\ Unit 405, Office Block, Hotel Equatorial Shanghai \\ No.65, Yan An Road (West), Shanghai, 200040, China \\ 中国上海市延安西路65号上海国际贵都大饭店办公楼 405 单元 \\ Phone: +86-21-62489820 \\ Fax: +86-21-62489821
}


(C) 2011 The Author(s). Licensee IntechOpen. This is an open access article distributed under the terms of the Creative Commons Attribution 3.0 License, which permits unrestricted use, distribution, and reproduction in any medium, provided the original work is properly cited. 